
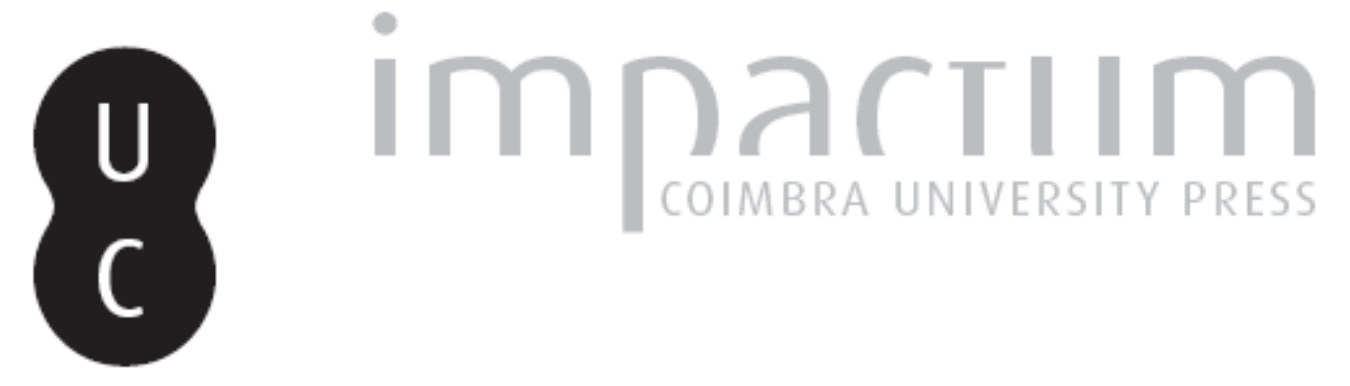

\title{
Plotinus and Augustine on evil and matter
}

\section{Autor(es): $\quad$ Silva, Maurizio Filippo Di}

Publicado por: Imprensa da Universidade de Coimbra; Annablume

URL persistente:

URI:http://hdl.handle.net/10316.2/43666

DOI:

DOI:https://doi.org/10.14195/1984-249X_23_7

Accessed : $\quad$ 26-Apr-2023 14:36:51

A navegação consulta e descarregamento dos títulos inseridos nas Bibliotecas Digitais UC Digitalis, UC Pombalina e UC Impactum, pressupõem a aceitação plena e sem reservas dos Termos e Condições de Uso destas Bibliotecas Digitais, disponíveis em https://digitalis.uc.pt/pt-pt/termos.

Conforme exposto nos referidos Termos e Condições de Uso, o descarregamento de títulos de acesso restrito requer uma licença válida de autorização devendo o utilizador aceder ao(s) documento(s) a partir de um endereço de IP da instituição detentora da supramencionada licença.

Ao utilizador é apenas permitido o descarregamento para uso pessoal, pelo que o emprego do(s) título(s) descarregado(s) para outro fim, designadamente comercial, carece de autorização do respetivo autor ou editor da obra.

Na medida em que todas as obras da UC Digitalis se encontram protegidas pelo Código do Direito de Autor e Direitos Conexos e demais legislação aplicável, toda a cópia, parcial ou total, deste documento, nos casos em que é legalmente admitida, deverá conter ou fazer-se acompanhar por este aviso.

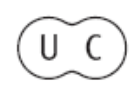




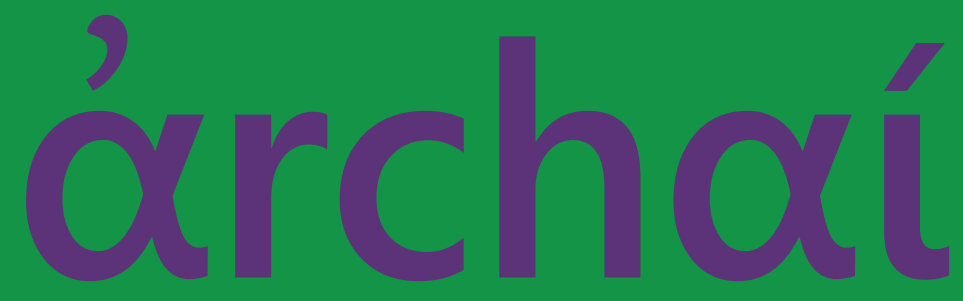

AS ORIGENS DO PENSAMENTO OCIDENTAL

THE ORIGINS OF WESTERN THOUGHT

May - Aug. 2018 


\section{Plotinus and Augustine on EVIL AND MATTER}

DI SILVA, M. F. (2018). Plotinus and Augustine on evil and matter. Archai, n. ${ }^{\circ} 23$, May-Aug., p. 205-227

DOI: https://doi.org/10.14195/1984-249X_23_7

Abstract: The aim of this paper is to examine whether and, if so, how far, the Augustinian notion of malum is related to Plotinus' concept of evil, as it appears in Ennead I. 8 [51]. The Augustinian notion of evil will be analyzed by focusing on the De natura boni, considering plurality and unity in Augustine's identification of malum and nihil, both in their ontological and axiological dimensions. Topics selected for special consideration will be, first, evil as lack of modus, species and ordo naturalis (De nat. b., 4), and, secondly, corruptio as cause of defectio boni (De nat. b., 6). The second part will analyze Plotinus' notion of evil, as spelled out in Ennead I, 8 [51], considering the Plotinian identity of to kakon and me on. Topics selected for analysis will be, first, the concept of evil as lack of measure, form and order (Enn. I. 8. 3), and secondly, the notion of to kakon as lack of good (Enn. I. 8. 5 ) simpliciter. The third part of this paper will consider the differences between Augustine's and Plotinus' identity of evil and non-being, as related to the notion of matter. Topics selected for analysis will be, firstly, Plotinus' identity of matter

\section{o’rchoí}

no 23, May-Aug. 2018 


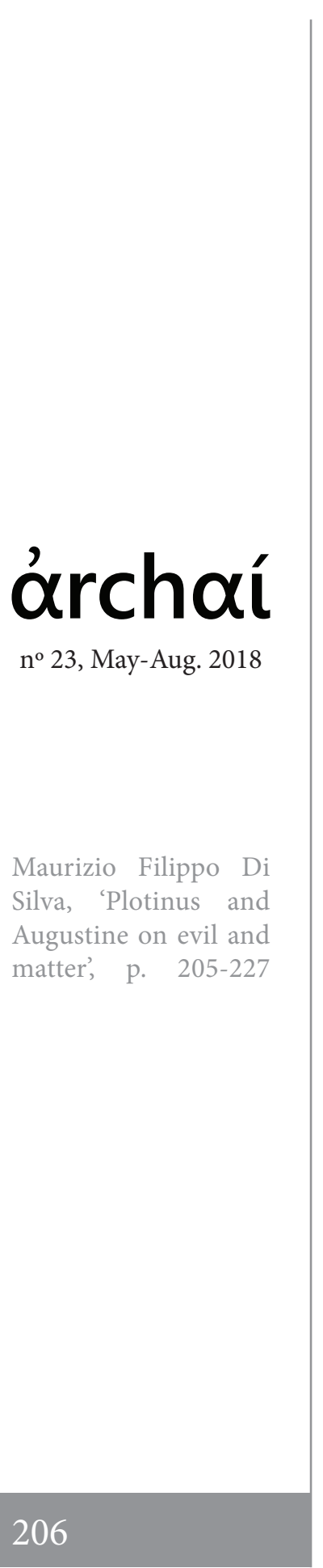

and evil (Enn. I. 8. 10), and, secondly, Augustine's concept of matter as capacitas formarum (De nat. b., 18). The conclusion will bring out how Plotinus' concept of steresis suggests both a different relation between evil and non-being while being closely resembling Augustine's pattern of malum and nihil. Keywords: Augustine, Plotinus, matter, evil, non-being.

\section{o’rchaí}

no 23, May-Aug. 2018

Maurizio Filippo Di

Silva, 'Plotinus and

Augustine on evil and matter', p. 205-227 


\section{INTRODUCTION}

The aim of this paper is to examine Augustine's reflections concerning the concept of evil, in order to identify whether - and to what extent - Augustine's notion of malum is related to Plotinus' concept of evil. This will be done by examining the Augustinian and Plotinian identification of evil and non-being as it appears in Ennead I. 8 and in De Natura Boni. More specifically, this study will first consider the similarities between the Augustinian and the Plotinian ontological-axiological patterns and define their specific features. Then, by looking at the concepts of evil that emerge from Augustine and Plotinus, it will examine the notions of non-being and matter as they are exposed in Ennead I. 8 and in De Natura Boni. Ultimately, this paper will demonstrate that Plotinus' notion of evil as steresis is akin to Augustine's concept of evil as defectus boni, confirming the theoretical relationship between Augustine's and Plotinus' idea of evil. ${ }^{1}$

\section{Augustine's identification of MALUM AND NIHIL}

The basic elements with which to examine Augustine's identification of malum and nihil first appear in his reflections, which are exposed in De Natura boni and concern the different kinds of goods and their constitutive features. In the taxonomy of goodness Augustine recognizes two classes of good beings endowed with a different axiological status, that is the highest good (God) on the one hand and great and small goods (souls and bodies) on the other hand. Augustine identifies the source of goodness

\section{ỏrchaí}

no 23, May-Aug. 2018

Maurizio Filippo Di Silva, 'Plotinus and Augustine on evil and matter', p. 205-227 


\section{o’rchaí}

no 23, May-Aug. 2018

in smaller goods with God's creation, which thus becomes the source of both the existence and goodness of creatures:

The Supreme Good, than which there is none higher, is God; for this reason $\mathrm{He}$ is immutable good, and therefore truly eternal and truly immortal. All other goods are from Him alone, but not of His substance. For that which is of His substance is identical with Himself, but the things which He has made are not what He Himself is. It follows that, if $\mathrm{He}$ alone is immutable, all the things which He has made, inasmuch as He has made them out of nothing, are mutable. For He is so almighty, that even out of nothing, that is, out of that which is utterly non-existent, He can make goods both great and small, both celestial and terrestrial, both spiritual and corporeal. ${ }^{2}$ (AUGUSTINE, 1955, 1, trans. by A.A. Moon)

Nevertheless, in his analysis Augustine does not

Maurizio Filippo Di Silva, 'Plotinus and Augustine on evil and matter', p. 205-227 simply state that the source of smaller goods (that is, souls and bodies) is God's creation, but also stresses that all beings are goods: "Inasmuch, therefore, as all goods whether great or small, whatever be their rank in the hierarchy of beings, can have existence only from God, and since, moreover, every nature is a good in so far as it is a nature, every nature can be only from the supreme and true God" (AUGUSTINE, 1955, 1). ${ }^{3}$ In order to understand the reason for such a total identification between beings and goods we have to understand what, according to Augustine, is the origin of the goodness of what is created. In De Natura Boni he clearly states that the axiological value of beings derives from the extent to which they are in accordance with their measure, form and order: 
For we Catholic Christians worship God, from Whom are all goods whether great or small, from Whom is every measure whether great or small, from Whom is every form whether great or small, from Whom is every order whether great or small. For certainly the more things possess of measure, form, and order, the better they are; but the less things possess of measure, form, and order the less good they are. ${ }^{4}$ (AUGUSTINE, 1955, 3. trans. slightly modified)

As this excerpt shows, the creation of goods corresponds to the creation of the principles of the goodness of beings.

Although these reflections explain what Augustine considers as the cause of the goodness of creatures, what still remains to be understood is the reason why all beings are goods. In order to do that we have to examine what Augustine says about the measure, form and order of beings, which shows that the principles of the goodness of beings are also the reason for their different degree of existence:

Where these three are great [i.e. measure, form and order], there are great goods; where they are small, there are small goods; where they are absent, good is absent. Again, where these three are great, there are great natures; where they are small, there are small natures; where they are non-existent, there is no nature. Therefore every nature is good. ${ }^{5}$ (AUGUSTINE, $1955,3)$

As we can see from Augustine's words the better things are measured, formed and ordered, the higher their ontological and axiological degree is.

\section{o’rchaí}

$n^{\circ} 23$, May-Aug. 2018

Maurizio Filippo Di Silva, 'Plotinus and Augustine on evil and matter', p. 205-227 


\section{o’rchaí}

no 23, May-Aug. 2018
Maurizio Filippo Di Silva, 'Plotinus and Augustine on evil and matter', p. 205-227
To understand the reason for such a relationship between the ontological and axiological dimensions of natures we have to consider that measure, form and order are not simply accidents of beings but correspond to the essence of beings. ${ }^{6}$ Thus, as principles of the existence of beings, they are at the same time the reason for their perfection (perfectio) and for their goodness.

Hence, if measure, form and order of natures are the cause of their existence and goodness, then there cannot be any evil nature among them (Augustine, $1955,4)$. As every being is indeed endowed with measure, form and order, it is in itself perfect therefore, good. ${ }^{7}$ If beings are in themselves good, it follows that evil corresponds to the non-being. In order to understand this we need to examine the plurality and unity of Augustine's identification of malum and nihil. In the light of the consideration concerning the relationship between the existence and goodness of beings we note first that evil corresponds to the corruption (corruptio) of measure, form and order: "Evil is nothing else than the corruption of the measure, the form, or the order of a nature" (Augustine, 1955, 4. trans. slightly modified). ${ }^{8}$ Indeed, if natures are what they are in virtue of the principles that produce their perfection, evil will correspond to the lack of them - therefore, to the non-being understood as their privatio. ${ }^{9}$ As we learn from Augustine's own words, evil is in that first meaning the non-being, understood here as the lack of the essence - therefore, of the existence of beings.

Having thus defined evil, Augustine analyses the source of that lack of good. Indeed, if every being is 
in itself endowed with measure, form and order, then evil, as the lack of these three elements, is not something that belongs to beings. What causes the lack of perfection of creatures is, according to Augustine, the movement of corruption of measure, form and order which, by decreasing their goodness, concurrently decreases their ontological degree: "If corruption should remove from corruptible things all measure, all form, and all order, no nature would remain" (Augustine, 1955, 6. trans. slightly modified). ${ }^{10}$ So, if all natures are good, evil corresponds to the ontological lack produced by corruption, which appears now as the movement in itself and not as an axiological form of it. To such an understanding of the reasons of the lack of measure, form and order of natures Augustine adds a reflection concerning the cause of movement that is essential in order to identify the group of elements related to his identification of malum and nihil. By examining the source of movement Augustine stresses that it corresponds to the nothingness out of which all natures are made: "Therefore, then, of whatsoever measure, of whatsoever form, of whatsoever order they are, they are such because God has made them; but they are not immutable, because they have been made from nothing" (Augustine, 1955, 10. trans. slightly modified). ${ }^{11}$ As shown by his reflections evil, as a lack of good, is the lack of existence produced by corruptio. This one is the product of the nothingness out of which things are created.

It is important to stress that the ontological-axiological pattern of Augustine's concept of evil does not emerge only in his reflections concerning evil as being but at the same time in the ones devoted to sin. Considering the results of moral evil Augustine states

\section{o’rchaí}

no 23, May-Aug. 2018

Maurizio Filippo Di Silva, 'Plotinus and Augustine on evil and matter', p. 205-227 


\section{o’rchaí}

no 23, May-Aug. 2018

Maurizio Filippo Di Silva, 'Plotinus and Augustine on evil and matter', p. 205-227 that they correspond to the corruption of human beings' measure, form and order $(1955,7) .{ }^{12}$ Thus sin, as action, corresponds to the movement of corruption - therefore, to a decrease of the ontological and axiological degree of human beings' nature. Augustine considers the lack of control on the desires of the soul and the body as the origin of such a movement of corruption, ${ }^{13}$ suggesting that nothingness is the origin of evil and that evil corresponds to the corruption of the essential features of beings.

In the light of these findings concerning the concept of evil we can now consider their ontological-axiological pattern. As already noticed in the reflections concerning the goodness of beings the measure, form and order of natures are the sources of both the existence and perfection (perfectio) of natures. Thus in such a perspective evil is, first, the lack of the essential elements of beings; therefore, it corresponds to the non-being as a lack of existence. Moreover, as measure, form and order are the sources of the existence of natures, evil (as defectus boni) will correspond to the result of that lessening of quantity or level (corruptio). As a cause of this lessened axiological perfection of natures Augustine indicates the nothingness ( ihil) out of which creatures are made, outlining an ontological-axiological pattern where evil is the non-being produced by corruptio. This one appears as a result of the nothingness out of which beings are created. Thus in Augustine's reflections evil emerges as the lack of existence produced by the movement originated from the non-being. On the contrary, the goodness of natures requires the permanence of measure, form and order (Augustine, 1955, 37). 


\section{Plotinus' identification of eVil and of} THE NON-BEING

In order to understand what Plotinus identifies as evil and non-being we need to examine first what is related to the statement of the problem. His reflections on Evil start indeed from the need to define Evil's nature, as this point is decisive to determine what kind of beings Evil may affect and whether it has or has not an Authentic-Existence (1966, I. 8 [51]. 1). ${ }^{14}$ In order to do that we have to know what Good is, because the nature of Evil is opposite to that of Good and at the same time because the knowledge of opposites is one and only: "But if, because opposites are known by one and the same kind of knowledge and evil is opposite to good, the knowledge of good will also be knowledge of evil, then those who mean to know evils must have a clear perception of good" (PLOTINUS, 1966, I. 8 [51]. 1). ${ }^{15}$ In such a perspective Plotinus examines what Good is, explaining that Good is that on which all beings depend and, at the same time, it is the measure and bound of everything (1966, I. 8 [51]. 2).

According to what he states in his introductory remarks Plotinus, having defined what Good is, subsequently examines what Evil is. As it is impossible to know what manifests itself as the very absence of Good (1966, I. 8 [51]. 2), the knowledge of Evil needs vision or removal (1966, I. 8 [51]. 9). As far as the object is concerned this corresponds to an understanding of it as a partial or absolute lack of good. Let us identify what that partial lack of good is. According to Plotinus, this corresponds to the partial lack of measure, form and order of beings

\section{ỏrchaí}

no 23, May-Aug. 2018

Maurizio Filippo Di Silva, 'Plotinus and Augustine on evil and matter', p. 205-227 


\section{o’rchaí}

no 23, May-Aug. 2018

which appears, for instance, in cases such as sickness, ugliness and poverty:

Illness is defect and excess of material bodies which do not keep order and measure; ugliness is matter not mastered by form; poverty is lack and deprivation of things which we need because of the matter with which we are coupled, whose very nature is to be need. ${ }^{16}$ (PLOTINUS, 1966, I. 8 [51]. 5)

As we can notice in Plotinus' words the measure, form and order of beings are the principles of their goodness while Evil, on the contrary, corresponds to their partial lack.

Plotinus then analyses another concept of Evil, the absolute lack of good and of what originates its goodness. If Good corresponds to the highest

Maurizio Filippo Di Silva, 'Plotinus and Augustine on evil and matter', p. 205-227 perfection Evil, as its opposite, is the absolute lack of measure, form and order (1966, I. 8 [51]. 3). ${ }^{17}$ Plotinus identifies such a concept of Evil with Matter which he now understands as what is absolutely devoid of measure - therefore, as the non-being: "Yes, but evil is not in any sort of deficiency but in absolute deficiency; a thing which is only slightly deficient in good is not evil, for it can even be perfect on the level of its own nature. But when something is absolutely deficient -and this is matter- this is essential evil without any share in good" (Plotinus, 1966, I. 8 [51]. 5). ${ }^{18}$ It is very important to stress that now Evil emerges at first as the non-being and, more specifically, as what is understood as Matter. At the same time we have to bear in mind that, according to Plotinus, this concept of Evil is related 
to the idea of it as a partial lack of being, and that these different notions of Evil need to be analyzed by examining their relationship.

Having defined the double meaning of the concept of Evil Plotinus considers how Matter, as Evil itself, generates the other evils. As he identifies form as the principle of the goodness of beings Evil, as the lack of it, corresponds to the outcome of an alteration of their status. More specifically, the lack of goodness of beings corresponds in Plotinus' analysis to the outcome of a deformation of realities caused by corruption (phthora), and the source of such a movement is identified with Matter:

For matter masters what is imaged in it and corrupts and destroys it by applying its own nature which is contrary to form, not bringing cold to hot but putting its own formlessness to the form of heat and its shapelessness to the shape and its excess and defect to that which is measured, till it has made the form belong to matter and no longer to itself. ${ }^{19}$ (PLOTINUS, 1966, I. 8 [51]. 8)

It is important to stress that what we have noted as regards Evil, which is a partial or absolute lack of good, appears in Plotinus' reflections concerning vices (1966, I. 8 [51]. 4-5), ${ }^{20}$ where intemperance and injustice turn out to be corruptions of the soul caused by Matter (1966, I. 8 [51]. 12-14).

In the light of the results of the analysis concerning the Plotinian concept of Evil we can now consider their ontological-axiological pattern. As noticed in the reflections concerning the principles of the goodness

\section{o’rchaí}

nº 23, May-Aug. 2018

Maurizio Filippo Di Silva, 'Plotinus and Augustine on evil and matter', p. 205-227 


\section{o’rchaí}

no 23, May-Aug. 2018
Maurizio Filippo Di Silva, 'Plotinus and Augustine on evil and matter', p. 205-227 of beings, beings are good because they are endowed with measure, form and order which are, therefore, what generates their existence and perfection. If Evil as a partial lack of good is an alteration of form, then in its ontological pattern it corresponds to the non-being. Moreover, after defining Evil as a partial lack of good, Plotinus examines the movement of deformation of beings (phthora) to identify the source of such a lack of good. As the cause of that kind of movement he indicates Matter. Despite its absolute lack of form Matter is, and Plotinus identifies it with the non-being, understood not as the pure nothing but as the image of Being (eikon tou ontos). ${ }^{21}$ In the light of these reasons we can notice that in Plotinus' analysis Evil corresponds to the non-being produced by corruption. This one now appears to be a result of the non-being. Hence Augustine's and Plotinus' respective ontological-axiological patterns display many similarities, but are at the same time different. In order to demonstrate this we need to examine the concept of matter as it emerges in Augustine's and Plotinus' reflections.

\section{The concept of Matter in Plotinus and in Augustine}

Although in both Plotinus and Augustine we can see an identification of evil and non-being, their ontological-axiological patterns are different. More precisely, this study has shown that Plotinus' notion of non-being corresponds to the concept of Matter, while in Augustine's reflections Evil is the non-being, simpliciter. An analysis of Plotinus' and Augustine's concept of Matter clarifies this difference. The Plotinian concept of Matter is visible in his defi- 
nition of Evil. For Plotinus Evil is the non-being and the non-being is Matter, an equivalence that merits further investigation. Plotinus indicates Evil as what is opposite to Good and as such is devoid of measure, form and order. He states that, as it is, Matter does not correspond to a being but to what is, without being endowed with an ontological pattern:

So that which underlies figures and forms and shapes and measures and limits, decked out with an adornment which belongs to something else, having no good of its own, only a shadow in comparison with real being, is the substance of evil (if there really can be a substance of evil); this is what our argument discovers to be the primal evil, absolute evil. ${ }^{22}$ (PLOTINUS, 1966, I 8 [51] 3)

Evil corresponds therefore to the non-being; its absolute lack of measure, form and order shows at the same time that according to Plotinus these are the principles of the existence of beings.

Having thus identified evil as non-being Plotinus considers the reason why Matter is evil. More precisely, considering why we can appropriately say that Matter, although devoid of quality, is evil, he remarks that it is like that exactly for its absolute lack of measure, form and order: "So, it [i.e. matter] is rightly said to be both without quality and evil; for it is not called evil because it has, but rather because it has not quality; so that perhaps it would not have been evil if it was a form instead of a nature opposed to form" (PLOTINUS, 1966, I. 8 [51]. 10). ${ }^{23}$ Plotinus' words suggest that Matter is evil because, as it is absolutely devoid of measure,

\section{o’rchaí}

no 23, May-Aug. 2018

Maurizio Filippo Di Silva, 'Plotinus and Augustine on evil and matter', p. 205-227 


\section{o’rchaí}

no 23, May-Aug. 2018
Maurizio Filippo Di

Silva, 'Plotinus and Augustine on evil and matter', p. 205-227 form and order, it is devoid of qualities. This allows us to acknowledge that Qualities derive from the principles of the goodness of beings.

As we can see from Plotinus' reflections Matter, as what is absolutely devoid of measure, form and order, corresponds to the absolute lack of good therefore, to Evil. Such a lack of goodness, produced by the absence of its principles, corresponds in the ontological dimension to the lack of existence of Matter. In the light of this we can state that, according to Plotinus, Matter is at the same time the non-being and Evil:

Indefiniteness and unmeasuredness and all the other characteristics which the evil nature has are contrary to the definition and measure and all the characteristics present in the divine nature; so the whole, too, is contrary to the whole. The evil nature, too, has a false being, primary and absolute falsehood; the being of the divine is true being. ${ }^{24}$ (PLOTINUS, 1966, I. 8 [51]. 6)

We have to stress that measure, form and order, as the principles of existence, are the principles of goodness. This allows us to state that his ontologicalaxiological pattern is based on them and that the idea of evil as both a partial and an absolute lack of goodness shows it. According to Plotinus, non-being is; therefore, the partial or absolute lack of good does not correspond to the non-being, simpliciter.

Instead Augustine's concept of hyle, although it displays many similarities with the Plotinian idea of Matter, corresponds to a good and not to 
Evil. At first Augustine characterizes hyle as what is absolutely devoid of form and, consequently, of quality. ${ }^{25}$ Both beings and their qualities derive from Matter:

but I mean by hyle, as did the ancients, a sort of matter utterly formless and without qualities, and out of which are formed the qualities which we perceive. Hence wood, too, is called $v \lambda \eta$ in Greek, because it is suitable for artisans, not in being able itself to make anything, but as material out of which something can be made. ${ }^{26}$ (AUGUSTINE, 1955, 18)

It is important to emphasize that Augustine understands Matter to be, although formless, able to receive a form, and he considers this as Matter's own nature: "Even this has the capacity for forms, since if it could not receive the form imposed by the artisan, it certainly would not be called matter" (Augustine, 1955, 18). ${ }^{27}$ So, according to Augustine, Matter is able to acquire a form and corresponds to the capacity itself to acquire existence and goodness. Although it is devoid of every principle of existence or perfection, Matter is; therefore, it is a good. More precisely, the capacity to receive form is the good with which Matter is endowed: "Furthermore, if form is a good, so that those who excel therein are called well-formed, as the beautiful are named from beauty, doubtless the capacity for form is likewise a good" (Augustine, 1955, 18). ${ }^{28}$ In the light of this we can conclude that in spite of similarities Augustine's and Plotinus' concepts of hyle are ontologically and axiologically ${ }^{29}$ different. According to Augustine, Matter is indeed a good and a being. This therefore shows

\section{ỏrchaí}

no 23, May-Aug. 2018

Maurizio Filippo Di Silva, 'Plotinus and Augustine on evil and matter', p. 205-227 


\section{o’rchaí}

no 23, May-Aug. 2018
Maurizio Filippo Di Silva, 'Plotinus and Augustine on evil and matter', p. 205-227 that Evil corresponds to non-being, simpliciter, and that the Augustinian ontological-axiological pattern is different from the one of Plotinus.

\section{Conclusions}

In the light of this analysis we can conclude that Plotinus' and Augustine's identification of evil and of the non-being initially displays a total correspondence between the elements of their patterns. Indeed in both cases evil is the non-being produced by the corruption which is originated by the non-being. Nevertheless, although such similarities seem to indicate a complete identification between their ontological-axiological patterns, the analysis of the two philosophers' respective notions of Matter clearly demonstrates that the Plotinian concept of the non-being is different from the Augustinian one. More specifically, whilst according to Plotinus the notion of the non-being corresponds to the concept of Matter as the absolute lack of ontological pattern, in Augustine the non-being is nothingness itself. It is very important to stress that the relationship between the Augustinian and Plotinian ontological-axiological pattern cannot be considered as a correspondence that only concerns their external features.

On the contrary, the concept of evil as a partial lack of good, as it appears both in Augustine's and Plotinus' reflections, shows at least in part a theoretical correspondence between the two philosophers. Examining whether evil is or is not simply a lack of good, and in reality trying to show that it corresponds to Matter, Plotinus states: "But the nature which is opposed to all form is privation; 
but privation is always in something else and has no existence by itself. So if evil consists in privation, it will exist in the thing deprived of form and have no independent existence" (PLOTINUS, 1966, I. 8 [51]. 11). ${ }^{30}$ Such a concept of evil, which describes evils that affect beings, ${ }^{31}$ can be noticed as being sometimes expressed exactly in the same way ${ }^{32}$ in Augustine's reflections. ${ }^{33}$ This therefore shows that Plotinus' concept of evil as a partial lack of existence and goodness is part of the Augustinian notion of evil itself and that the Plotinian ontological-axiological pattern acts in Augustine's reflections concerning evil (as the defectus boni) as their basic element.

\section{ENDNOTES}

As is well known, Augustine's knowledge of Plotinus' philosophy is contested. Nevertheless, it is important to stress that what raises doubts is the exact determination of which Plotinian works he read, and not his knowledge of Plotinian Neoplatonism. CATAPANO (2006, p. CXXIII-CXXIV) wrote: "Il problema di quali fossero questi «libri di Platonici» letti da Agostino ha appassionato molto gli studiosi. Pare abbastanza evidente che essi coincidono almeno in parte con i Plotini paucissimi libri di beata v. $i, 4$. Sono state avanzate varie ipotesi circa il numero e l'identità dei trattati plotiniani in questione, ma l'assenza di citazioni letterali nei primi scritti agostiniani e di altre notizie sulla traduzione fatta da Mario Vittorino pone un serio ostacolo alla trasformazione delle congetture in sicure certezze [...] Si può comunque ritenere fuori discussione che tramite $i$ «libri dei Platonici» Agostino abbia incontrato direttamente il neoplatonismo plotiniano (con cui forse era già venuto inconsapevolmente in contatto mediante certe omelie di Ambrogio) e porfiriano, e che questo incontro abbia segnato più di qualunque altro, sul piano filosofico, il suo pensiero." On the relationship between Augustine's and Plotinus' concept of evil see: Bezançon (1965, p. 135); Rist (1974).

2 See: "Summum bonum quo superius non est, Deus est; ac per hoc incommutabile bonum est; ideo vere aeternum et vere inmortale. Cetera omnia bona nonnisi ab illo sunt, sed non de illo. De illo enim

\section{ỏrchaí}

n²3, May-Aug. 2018

Maurizio Filippo Di Silva, 'Plotinus and Augustine on evil and matter', p. 205-227 


\section{o’rchaí}

$n^{\circ} 23$, May-Aug. 2018
Maurizio Filippo Di

Silva, 'Plotinus and Augustine on evil and matter', p. 205-227 quod est, hoc quod ipse est; ab illo autem quae facta sunt, non sunt quod ipse. Ac per hoc, si solus ipse incommutabilis, omnia quae fecit, quia ex nihilo fecit, mutabilia sunt. Tam enim omnipotens est, ut possit etiam de nihilo, id est ex eo quod omnino non est, bona facere, et magna et parva, et caelestia et terrena, et spiritalia et corporalia."

3 See: "Quia ergo bona omnia, sive magna sive parva, per quoslibet rerum gradus, non possunt esse nisi a Deo; omnis autem natura, in quantum natura est, bonum est; omnis natura non potest esse nisi a summo et vero Deo."

4 See: "Nos enim catholici christiani Deum colimus, a quo omnia bona sunt seu magna seu parva, a quo est omnis modus sive magnus sive parvus, a quo omnis species sive magna sive parva; a quo omnis ordo, sive magnus sive parvus. Omnia enim quanto magis moderata, speciosa, ordinata sunt, tanto magis utique bona sunt; quanto autem minus moderata, minus speciosa, minus ordinata sunt, minus bona sunt." For a detailed discussion on Augustine's concepts of measure, form and order see Beierwaltes (1994, p. 143-157); Bettetini (1994, p. 125-222); La Bonnardière (1970); Reale (2001, p. 52-61); Roche (1941, p. 350-376).

5 See: "Haec tria ubi magna sunt, magna bona sunt; ubi parva sunt, parva bona sunt; ubi nulla sunt, nullum bonum est. Et rursus haec tria ubi magna sunt, magnae naturae sunt; ubi parva sunt, parvae naturae sunt; ubi nulla sunt, nulla natura est. Omnis ergo natura bona est."

6 See: De Moribus Manichaeorum, II. 2. 2.

7 See: De Genesi contra Manichaeos, I. 8.13.

$8 \quad$ See: "Proinde cum quaeritur unde sit malum, prius quaerendum est quid sit malum. Quod nihil aliud est quam corruptio vel modi vel speciei vel ordinis naturalis." On the similarities between Plotinus' and Augustine's reflections about the order of the analyses concerning Evil, see: Ennead, I. 8 [51]. 1.

9 See: De Natura Boni, 16.

10 See: "Corruptio autem si omnem modum, omnem speciem, omnem ordinem rebus corruptibilibus auferat, nulla natura remanebit." See: De Natura Boni, 15; De Moribus Manichaeorum, II. 5.7-6.8. On Augustine's reflections concerning the movement of corruption of modus, species and ordo see De Capitani (1980, p. 640-669; 1981, p. 132-156); Di Silva (2015, p. 105-118); Müller (1986, p. 47-53).

11 See: "Ideo ergo quocumque modo, quacumque specie, quocumque ordine sunt, quia Deus est a quo factae sunt; ideo autem non incommutabiles sunt, quia nihil est unde factae sunt." See: De Natura Boni, 1. 
12

See: "Creaturis autem praestantissimis, hoc est rationalibus spiritibus, hoc praestitit Deus, ut si nolint, corrumpi non possint, id est, si oboedientiam conservaverint sub Domino Deo suo ac sic incorruptibili pulchritudini eius adhaeserint; si autem oboedientiam conservare noluerint quoniam volentes corrumpuntur in peccatis, nolentes corrumpantur in poenis." See: De Natura Boni, 23; De libero Arbitrio, II. 20. 54 .

13 See: De libero Arbitrio, II. 20. 54.

14 Translation by A.H. Armstrong.

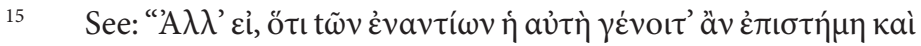

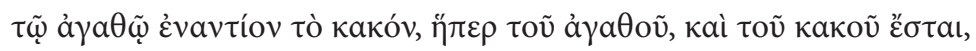

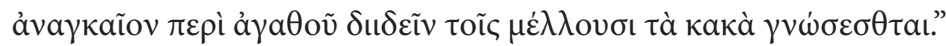

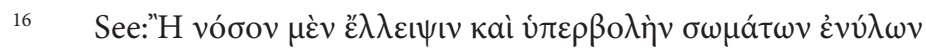

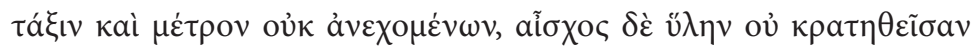

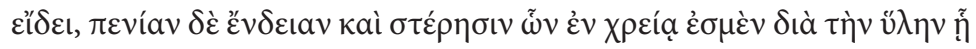

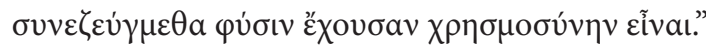

17 On the opposition between Good and Evil and on vision and removal as methodological way to know what the Evil is, see: Ennead, I. 8 [51]. 6 .

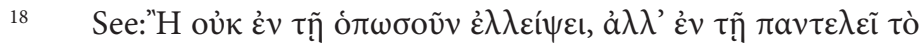

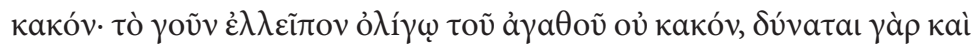

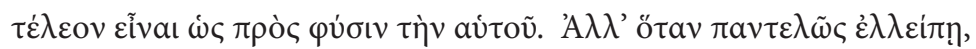

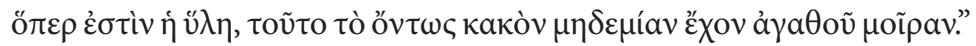
On the ontological status of Evil as non-being, see: Ennead, I. 8 [51]. 3. For the relationship between matter and evil see Chiaradonna (2009, p. 158-162); Corrigan (1996).

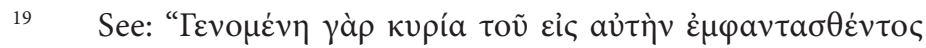

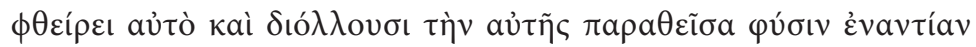

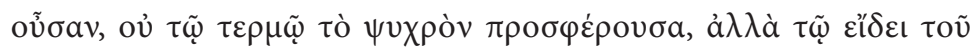

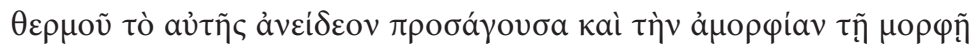

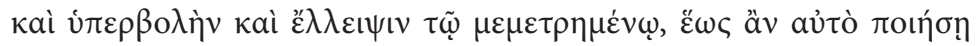

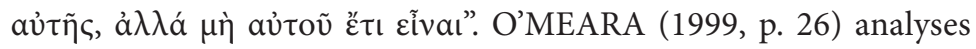
more in depth the issue of matter as evil and as the origin of other evils: "Largument de «l'unité d'une multiplicité» des premiers chapitres du traité qui conduit a l'existence d'un mal absolu, d'un mal en soi, la matière, distingue aussi de ce fait ce mal en soi de tout ce qui est mauvais en raison d'un quelconque rapport avec le mal en soi. Il s'agit des maux secondaires, les choses qui deviennent mauvaises par une participation ou une assimilation au mal en soi (3, 30-34; 8, 37-44). Ces choses sont

\section{ỏrchaí}

no 23, May-Aug. 2018

Maurizio Filippo Di Silva, 'Plotinus and Augustine on evil and matter', p. 205-227 


\section{o’rchaí}

no 23, May-Aug. 2018

des maux "par accident», en raison d'une rapport avec le mal en soi, tout comme des êtres sont bons en raison de leur rapport avec le Bien." For a detailed discussion on this topic see O'Brien (1971, p. 113-146), (1996, p. 171-195); Narbonne (1994, p. 113-133); Rist (1961, p. 151164); Schäfer (2004, p. 266-294).

20 See: Ennead, I. 8 [51]. 8.

21 See: Ennead, I. 8 [51]. 3.

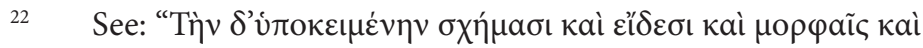

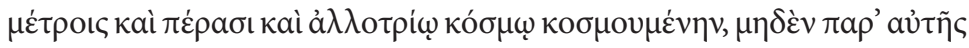

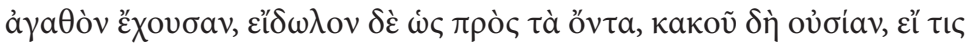

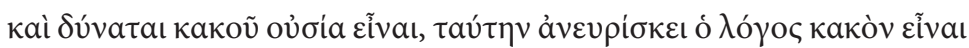

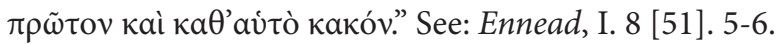

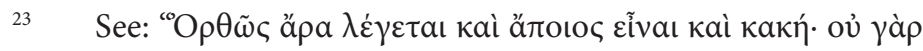

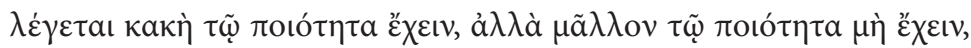

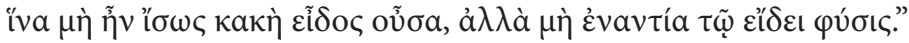

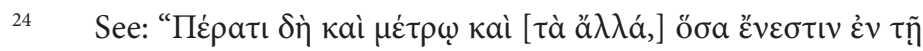

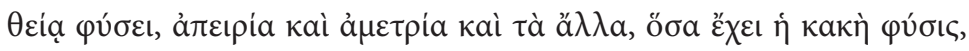

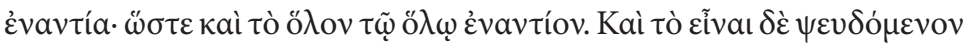

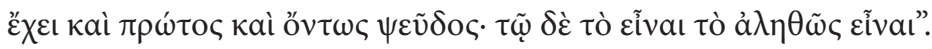

25 On Plotinus' reflections concerning Matter and Qualities, see: Ennead I. 8 [51]. 10-11.

Maurizio Filippo Di

Silva, 'Plotinus and Augustine on evil and matter', p. 205-227
26 See: "sed hylen dico quandam penitus informem et sine qualitate materiem, unde istae quas sentimus qualitates formantur, ut antiqui dixerunt. Hinc enim et sylva greace $v \lambda \eta$ dicitur, quod operantibus apta sit, non ut aliquid ipsa faciat, sed unde aliquid fiat."

$27 \quad$ See: "Habet enim et ipsa capacitatem formarum; nam si capere impositam ab artifice formam non posset, nec materies utique diceretur."

$28 \quad$ See: "Porro si bonum aliquod est forma, unde quia ea praevalent formosi appellantur, sicut a specie speciosi, procul dubio bonum aliquid est etiam capacitas formae; sicut quia bonum est sapientia, nemo dubitat quod bonum sit capacem esse sapientiae”. According to Augustine, if Matter is good, it is God's creature (De Nat. Boni, 18). It is very important to stress that the goodness of Matter allows us to solve the problem concerning its origin, as it emerges in Plotinus' reflections (see: Ennead, I. 8 [51]. 7).

29 As for the problems related to the Augustinian concept of Matter, that is its ontological-axiological state, see: Conf. XII. 1.1-13.16.

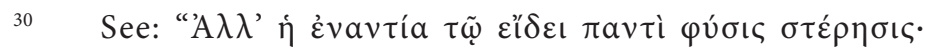

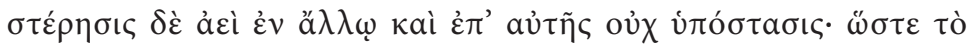




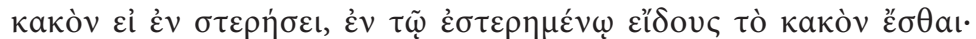

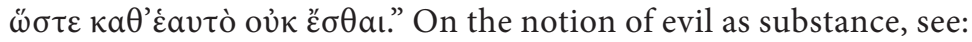
Ennead, I. 8 [51]. 3.

31 See: Ennead, I. 8 [51]. 1.

32 See: De Natura Boni, 14-15; 21; 23.

33 See: De Natura Boni, 17.

\section{BIBLIOGRAPHY}

ARMSTRONG, A. H. (1966). Plotinus. Ennead I (translation). Cambridge, Harvard University Press.

BEIERWALTES, W. (1994). Agostino e il neoplatonismo cristiano. Milan, Vita e Pensiero.

BETTETINI, M. (1994). La misura delle cose: struttura e modelli dell'universo secondo Agostino d'Ippona. Milan, Rusconi.

BEZANÇON, J. N. (1965). Le mal et l'existence temporelle chez Plotin et Saint Augustin. Recherches Augustiniennes 3. p. 133-160.

CATAPANO, G. (2006). Introduzione Generale. In: Aurelio Agostino. Tutti i dialoghi. Milan. Bompiani, p. IX-CLXVI.

CHIARADONNA, R. (2009). Plotino. Urbino, Carocci editore.

CORRIGAN, K. (1996). Plotinus' Theory of MatterEvil and the Question of Substance: Plato, Aristotle, and Alexandre of Aphrodisias. Leeuven, Peeters.

DE CAPITANI, F. (1980). «Corruptio» negli scritti antimanichei di S. Agostino. I. Rivista di Filosofia Neoscolastica 72. p. 640-669; (1981). II, 73. p. 132-156.

\section{o’rchaí}

$n^{\circ}$ 23, May-Aug. 2018

Maurizio Filippo Di Silva, 'Plotinus and Augustine on evil and matter', p. 205-227 


\section{o’rchaí}

no 23, May-Aug. 2018

Maurizio Filippo Di Silva, 'Plotinus and Augustine on evil and matter', p. 205-227
DI SILVA, M. F. (2015). Agostino e il problema del negativo. Pluralità e unità dell'identità di male e nulla. In: ALICI, L. (ed.). I conflitti religiosi nella scena pubblica. Roma. Città Nuova, p. 105-118.

MÜLLER, C. (1986). Corruptio-incorruptio. In: MAYER, C. (ed.). Augustinus-Lexikon. Basel. Schwabe, p. 47-53.

LA BONNARDIÈRE, A. M. (1970). Biblia Augustiniana. Paris (France), Études Augustiniennes.

MOON, A. A. (1955). The De Natura Boni of Saint Augustine (translation). Washington, Catholic University of America Press.

NARBONNE, J. M. (1994). La Métaphysique de Plotin. Paris (France), Vrin.

O'BRIEN, D. (1971). Plotinus on evil: a study of matter and the soul in Plotinus' conception of human evil. In: SCHUHL, M.; HADOT, P. (eds.). Le Néoplatonisme: Royaumont, 9-13 juin 1969. Paris. Editions du Centre National de la Recherche Scientifique, p. 113-146.

O'BRIEN, D. (1996). Plotinus on matter and evil. In: GERSON, L. P. (ed.). The Cambridge Companion to Plotinus. Cambridge. The Cambridge University Press, p. 171-195.

O’MEARA, D. (1999). Introduction. In: Plotin. Traité 51 (I, 8). Paris. Éditions du Cerf, p. 11-41.

REALE, G. (2001). Introduzione. In: Aurelio Agostino. Natura del bene. Milan. Bompiani, p. 13-103. 
RIST, J. (1961). Plotinus on matter and evil. Phronesis 6. p. 151-164.

RIST, J. (1974). Plotinus and Augustin on evil. In: AA. VV., Plotino e il Neoplatonismo in Oriente e in Occidente (Roma, 5-9 ottobre 1970). Rome, Accademia Nazionale dei Lincei.

ROCHE, W. J. (1941). Measure, Number, and Weight in St. Augustine. New Scholasticism 15. p. 350-376.

SCHÄFER, C. (2004). Matter in Plotinus's Normative Ontology. Phronesis 143. p. 266-294.

Submitted in February and accepted for publication in April, 2017

\section{o’rchoí}

$n^{\circ}$ 23, May-Aug. 2018

Maurizio Filippo Di

Silva, 'Plotinus and Augustine on evil and matter', p. 205-227 
